$$
\text { DOE/ER/61877-T2 }
$$$$
\mathcal{N} \text { (ational Center for Atmospheric Research }
$$$$
\text { Atmospheric Chemistry Division }
$$$$
\text { P. O Box 3000, Boulder CO } 80307
$$

March 1, 1996

\section{Summary of Research for FY-1995; Progress report}

Guy Brasseur, PI

\author{
David Erickson, Co-I \\ XueXi Tie, Co-I \\ Stacy Walters, Co-I.
}

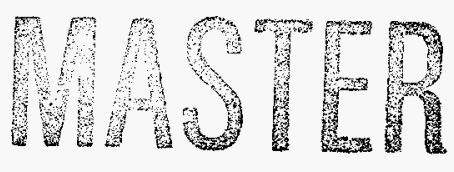

The object of this proposal is to study the reduction in mid-latitude stratospheric ozone and to estimate the budget of tropospheric ozone.

The product of this proposal include: (1) the estimation of dilution of air masses processed by polar stratosphcric clouds inside the polar vortex during winter; and (2) the destruction of ozone via hcterogencous reactions on the surface of acrosol particles which are present at all latitudes, especially after large volcanic cruptions such as Mt. Pinatubo; (3) to quantify photochemical production and destruction of $\mathrm{O}_{3}$ in the free troposphere; (4) to quantify export of ozone from "polluted" to remote regions, and (5) to quantify cross-tropopause exchanges of $\mathrm{O}_{3}$ and other species.

The approach of this proposal is to use and to improve our two-dimensional and thrcedimension global chemical/dynamical models including: (1) a ncw version of our twodimensional cliemical-radiative-dynamical model with microphysical process of sulfate acrosols and polar stratospheric clouds (PSCs), and heterogeneous conversions on the surfaces of sulfate 


\section{DISCLAMrax}

Portions of this docoment may be illegibie in electronic image products. Images are produced from the best available origional doecoment 
acrosols and PSCs; (2) the stratospheric version of three-dimensional off-line chemical-transport model (STARS) with a relatively high horizonlal resolution (2.8 degrec in latitudes) with nucrophysical forination of PSCs to study the role of transport on the mid-latitude ozone reduction; (3) the tropospheric version of a thrce-dimensional off-line chemical-transport model (MOZART) with detailed surface emissions and hydro-carbon reactions to estimate the tropospheric ozorie budget and perturbations; (4) the intermediate model of the global and annual evolution of species (IMAGES) with detailed chemical rcactions but relatively lower resolution to study the sensitivities of natural and anthropogenic perturbations on tropospheric ozone.

In 1995, several srudies have becn completed and are summarized in the following.

\section{Stratospheric ozonc depletion}

The coupled chemical radiative, dynamical and microphysical 2-D model is used to assess the response of stratospheric ozone to the injection of sulfur following the eruption of ML Pinatubo. Model calculations suggest that, during the first ycar (July/1991 to June/1992) following the volcanic eruption, the obscrved changes in the ozone amount integrated berween $65^{\circ} \mathrm{S}$ and $65^{\circ} \mathrm{N}$ have been caused primarily by changes in the meridional circulation (associated with beating by the volcanic cloud in the tropics) and in the photolysis rate of molccules such as ozone (associated with backscaltcring of light by the cloud). During the second year after the eruption, as the aerosol has been dispersed at all latitudes and, in particular, has reached the polar region, the largest contribution to ozone reduction results from the haterogencous chemical conversion of $\mathrm{N}_{2} \mathrm{O}_{5}$ and $\mathrm{ClONO}_{2}$ on the surface of the aerosol particles.

Modcl calculations also suggest that the ozone decrease observed a few years after the eruptions of Mt. Pinatubo and El Chichon may have been unique in the Earth's history, and is directly linked to the emission in the atmosphere of industrially manufactured chlorofluorocarbons. For chlorine loadings typical of the pre-1980 pcriod, the ozone column abundance should have incrcased after a large volcanic eruption. After 1980, as a result of growth in chlorine loading, the response of ozone became ncgative in winter at mid-and high latitudes. In the furure, the 
response of ozcne is expected to become positive again, if the production of chlorofluorocarbons is sufficiently reduced.

We have devcloped a global threc-dimensional transport/chcinical model of the stratosphere nayncd STARS (Study of Transport And Chemical Reactions in the Stratosphere), which includes a representation of the formation of polar stratospheric clouds (PSCs) and detailed hetcrogeneous reactions on the surface of PSCs and sulfate aerosols.

We have used this model to study the effects of springtime "Antarctic ozone hole" on midlatitude and upper tropospheric ozone. The calculation shows a maximum total ozone depletion of $40 \%$ over Antarctica in October. After the brcakdown of the polar vortex in December, air with deplcted ozone is transported to Midlatitude in the Southern Hemisphcre, resulting in a $2-4 \%$ ozone decrease at Midlatitude in December and a $1 \%$ decrease in the tropics. Ozone-poor aimasses are also transported to the troposphere, and produce a significant decrease (20-30\%) in upper tropospheric ozone. The model results also show that heterogeneous conversion of bronine reservoirs has an impostant effect on the formation of reactive chlorine, which could result an important effecr on the ozone concentration at midlatitude, especially after the large volcanic cruptions of 1980's and 1990's.

\section{Tropospheric ozone budget}

We have also completed the development of the IMAGES model, which describes the thrcedimensional distribution of approximately 50 chemical compounds from the surface to the 50 mbar level. The model has been used to assess the impact of aircraft emissions on tropospheric ozone and to investigate potential causes for the recently obscrved decrease in CO abundances.

Most recently, we have completed the development of a global threc-dimensional model (MOZART) which simulates the distribution of ozone and its precursors in the troposphere and lower stratosphcre. The model, which includes approximately 40 chemical spccies and 120 chemical and photochemical reactions, is driven by winds and temperatures provided by the NCAR Community Climate Model (CCM-2). The spatial resolution is 2.8 degrees in longiude 
and latitude, with 18 levels in the vertical from the surface to $1 \mathrm{mb}$. Boundary layer exchanges, cloud convection, and aqueous phase chemistry are included in the model. Surface emissions are based on pre-established inventorics.

\section{Publications:}

Tie, X., G. P. Brasseur, B. Briegleb, and C. Granier, Two-dimensional simulation of Pinatubo aerosol and its effect on stratospheric ozone, J. Geophys. Res., 99, 20545-20562, 1994.

Tie, X., and G. P. Brasseur, The response of stralospheric ozone to volcanic eruptions: Sensitivity to atmospheric chlorine load, Geophys. Res. lett., 22, 3035-3038, 1995.

De Rudder, A, N. Larsen, X. Tie, C. Granier, and G. P. Brasseur, Model study of polar stratospheric clouds and their effects on stratospheric ozone: Part I- Model description, J. Geophys. Res., inpresscd, 1996.

Tie, X., G. P. Brasseur, C. Granicr, A. De Rudder, N. Larsen, Model study of polar stratospheric clouds and their effects on stratosphcric ozone: Part II-Modcl results, J. Geophys. Res., inpressed, 1996.

Tie, X., and G. P. Brasseur, The importance of heterogenous bromine chemistry in the lower stratosphere, Submitted to Geophys. Res. lett., 1996.

Brasseur, P. G., X. Tic, P. Rasch, and F. Lcfevre, A threc-dimcnsional simulation of the Antarctic ozone hole: The impact of anthropogenic chlorine on the lower stratosphcre and upper troposphere, Submitted to J. Geophys. Res. 1996.

Muller, J.-F., and G. P. Brasseur, IMAGES: A three-dimensional chemical transport model of the global rroposphere, J. Geophys. Res., 100, 16445-16490, 1996.

Brasseur, G. P., Atmospheric Impact of NOx emissions by subsonic aircraft: A treedimensional model study, J. Geophys. Res., 101, 1423-1428, 1996. 
Gramier, C., J.-F. Muller, S. Madronich, and G. P. Brasseur, Possiblc causes for the 1990-1993 decrease in the global tropospheric $\mathrm{CO}$ abundance: a threc-dimensional study, submitted to Atmospheric Environment.

\section{DISCLAIMER}

This report was prepared as an account of work sponsored by an agency of the United States Government. Neither the United States Government nor any agency thereof, nor any of their employees, makes any warranty, express or implied, or assumes any legal liability or responsibility for the accuracy, completeness, or usefulness of any information, apparatus, product, or process disclosed, or represents that its use would not infringe privately owned rights. Reference herein to any specific commercial product, process, or service by trade name, trademark, manufacturer, or otherwise does not necessarily constitute or imply its endorsement, recommendation, or favoring by the United States Government or any agency thereof. The views and opinions of authors expressed herein do not necessarily state or reflect those of the United States Government or any agency thereof. 